\title{
Inflammation in Vein Graft Disease
}

\author{
Margreet R. de Vries* and Paul H. A. Quax \\ Department of Surgery, Einthoven Laboratory for Experimental Vascular Medicine, Leiden University Medical Center, \\ Leiden, Netherlands
}

Bypass surgery is one of the most frequently used strategies to revascularize tissues downstream occlusive atherosclerotic lesions. For venous bypass surgery the great saphenous vein is the most commonly used vessel. Unfortunately, graft efficacy is low due to the development of vascular inflammation, intimal hyperplasia and accelerated atherosclerosis. Moreover, failure of grafts leads to significant adverse outcomes and even mortality. The last couple of decades not much has changed in the treatment of vein graft disease (VGD). However, insight is the cellular and molecular mechanisms of VGD has increased. In this review, we discuss the latest insights on VGD and the role of inflammation in this. We discuss vein graft pathophysiology including hemodynamic changes, the role of vessel wall constitutions and vascular remodeling. We show that profound systemic and local inflammatory responses, including inflammation of the

OPEN ACCESS

Edited by:

Masanori Aikawa

Harvard Medical School,

United States

Reviewed by:

Vasilios Gabriel Athyros,

Aristotle University of

Thessaloniki, Greece

Christoph Eugen Hagemeyer,

Monash University, Australia

*Correspondence: Margreet R. de Vries

m.r.de_vries@/umc.nl

Specialty section:

This article was submitted

to Atherosclerosis and

Vascular Medicine,

a section of the journal

Frontiers in Cardiovascular Medicine

Received: 02 November 2017

Accepted: 08 January 2018

Published: 24 January 2018

Citation:

de Vries MR and Quax PHA (2018) Inflammation in Vein Graft Disease.

Front. Cardiovasc. Med. 5:3.

doi: 10.3389/fcvm.2018.00003 perivascular fat, involve both the innate and adaptive immune system.

Keywords: cardiovascular disease, bypass graft, saphenous vein, vein graft disease, inflammation, innate immunity, atherosclerosis

\section{INTRODUCTION}

Occlusive atherosclerotic disease is a leading cause of mortality and morbidity worldwide. The most commonly used revascularization strategies to unblock or circumvent atherosclerotic lesions are balloon angioplasty (with or without stenting), endarterectomy and bypass surgery. For patients with left main coronary artery disease $(\mathrm{CAD})$, three-vessel CAD and patients with late-stage peripheral artery occlusive disease (PAOD) bypass surgery is the primary standard of care (1-4). For patients receiving a single graft the left internal mammary artery is the graft of choice, since these give the best patency rates $(5,6)$. However, for bypassing multiple lesions, complex lesions or long diffuse lesions (especially in peripheral artery disease) veins are frequently necessary as a conduit, Figure 1A. Among veins the great saphenous vein is the most obvious conduit and is almost exclusively used as graft in patients with PAOD (7). Advantages of the saphenous vein include the length, which allows the use for multiple grafts, its superficial location for easy accessibility and the expendability (after removal of the vein the surrounding tissue is still perfused by other vessels). Unfortunately, patency rates of vein grafts are poor compared to arterial grafts (1). Due to acute thrombosis patency rates of vein grafts decrease with $10 \%$ within the first month (1). Intimal hyperplasia and accelerated atherosclerosis lead to a $40 \%$ overall patency after 10-20 years, Figures 1B,C $(8,9)$. Risk factors associated with vein graft disease (VGD) include age, race, gender, hypercholesterolemia, diabetes mellitus, and chronic kidney disease (10-14). Also factors associated with the surgery contribute to reduced patency. These include the location and quality of the artery where the bypass will be attached, and quality and handling of the venous conduit. Collection of venous conduits with the so called "no touch technique" in which veins are harvested including perivascular fat improve patency rates (15). 

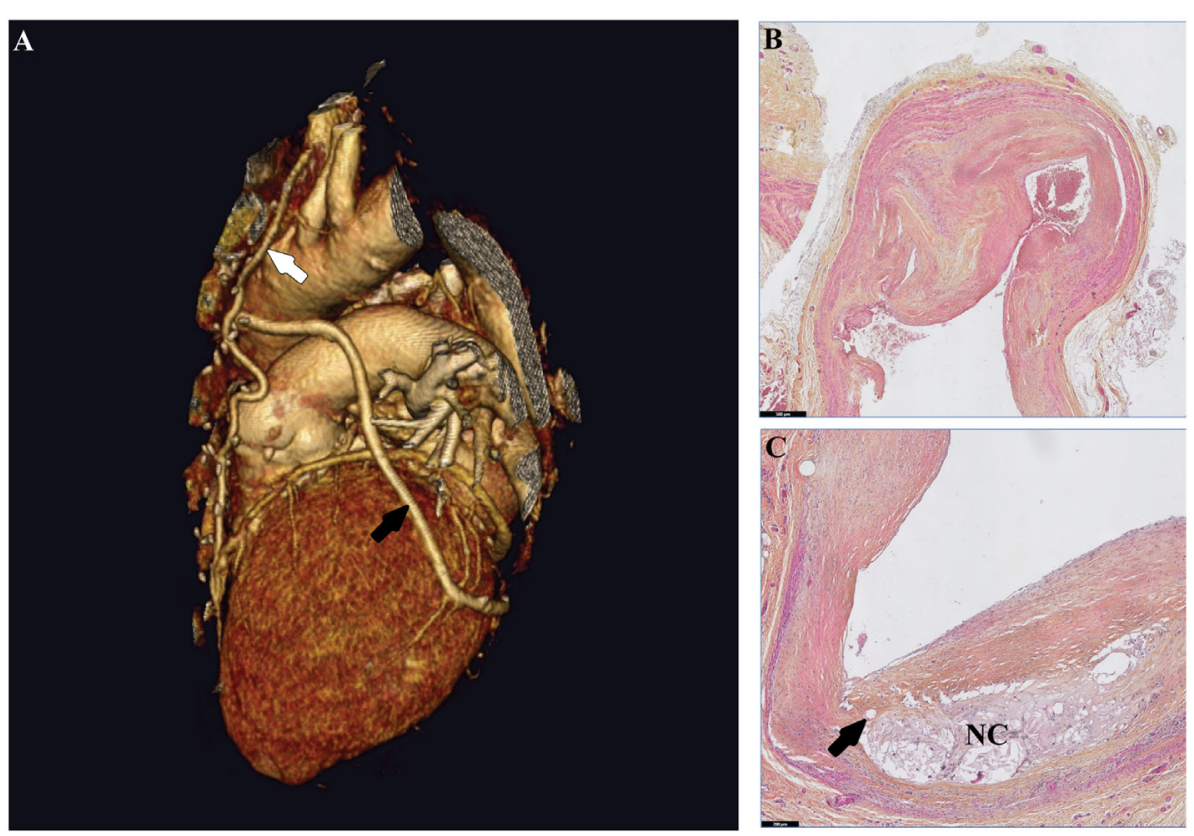

FIGURE 1 | Human vein grafts in macroscopic and microscopic views. (A) 3D reconstruction of a heart. In this CT scan, a saphenous vein segment (black arrow) is grafted from the aorta to the ramus circumflexus. The left internal mammarian artery graft (white arrow) is connected to the left anterior descending coronary artery. (B) A failed human saphenous vein graft displaying in the intimal hyperplasia, extensive smooth muscle cell accumulation, and extracellular matrix deposition. (C) Accelerated atherosclerosis in a human vein graft lesion is characterized by a decellularized necrotic core with cholesterol crystals and calcification (NC) and neovessels (arrow).

In this review, we emphasize the role of inflammatory processes during vein graft remodeling and show how inflammation is involved in all phases leading to VGD, Figure 2. Currently, statins and aspirin are the only treatment options recommended for both CAD and PAOD patients (4, 16-18). Although a lot of research is performed on new targets and therapies it is somewhat disappointing that no effective new strategies that prevent VGD have come up. The recent published results of IL1 $\beta$ inhibition with canakinumab resulting in positive effects on atherosclerosis (19) are very encouraging for new studies targeting inflammation in VGD. In this review, we discuss the pathophysiology of vein grafts and the role of inflammatory mediators during this process based on preclinical and clinical research.

\section{VEIN GRAFT REMODELING}

Remodeling of the vessel wall of the vein grafts is a crucial process during all subsequent stages of VGD. The initial remodeling event is the distension of the venous segment during surgical harvesting and subsequent controlling for proper ligation of all side branches. Usually this is done by checking the lack of leakage of fluids via these side branches when pressure is inflicted on the isolated venous segment, leading to a profound distension of the venous segment. In the next stage, directly after grafting the venous segment in the arterial circulation, the vein graft will be distended again due to the exposure to the arterial blood pressure. Both forms of distension lead to serious damage of the vessel wall (20). Not only endothelial cells become damaged or activated but also the media becomes activated due the distension injury, leading to activation of smooth muscle cells (SMCs) and degradation of several components of the extracellular matrix (ECM) in the media as well as the adventitia. These degradation products of matrix elements like hyaluronic acid, proteoglycans and fibronectin are damage-associated molecular patterns (DAMPs), which can act as endogenous ligands for toll-like receptors (TLRs), thus triggering an initial inflammatory response in vein graft remodeling. Moreover, the ischemia-reperfusion period during and after surgery can lead to generation of DAMPs and as well as reactive oxygen species, resulting in damage of vascular cells and upregulation of cytokines (1). Within the first days to weeks this results in influx of inflammatory cells in the vein graft vessel.

The next step in vein graft remodeling relates to the adaptation of the venous segment to the arterial blood pressure. In the media an arterialization process is initiated based on the proliferation of SMCs. This initially beneficial vascular remodeling process, however, may result in an uncontrolled proliferation and migration of SMCs and even myofibroblasts originating from the adventitia and triggers intimal hyperplasia (1). The concomitant outward remodeling of the vein grafts usually compensates for the pathological lumen loss. However, outward remodeling does not occurs always, resulting in situations in which neointima formation leads to inward remodeling as a result of pathological intimal hyperplasia and lumen loss, Figure 3 (21, 22). This is often accompanied or even enhanced by infiltration of inflammatory cells, mainly macrophages, into the vein graft wall (23). Moreover, in the later stage of vein graft remodeling, under hypercholesterolemic 


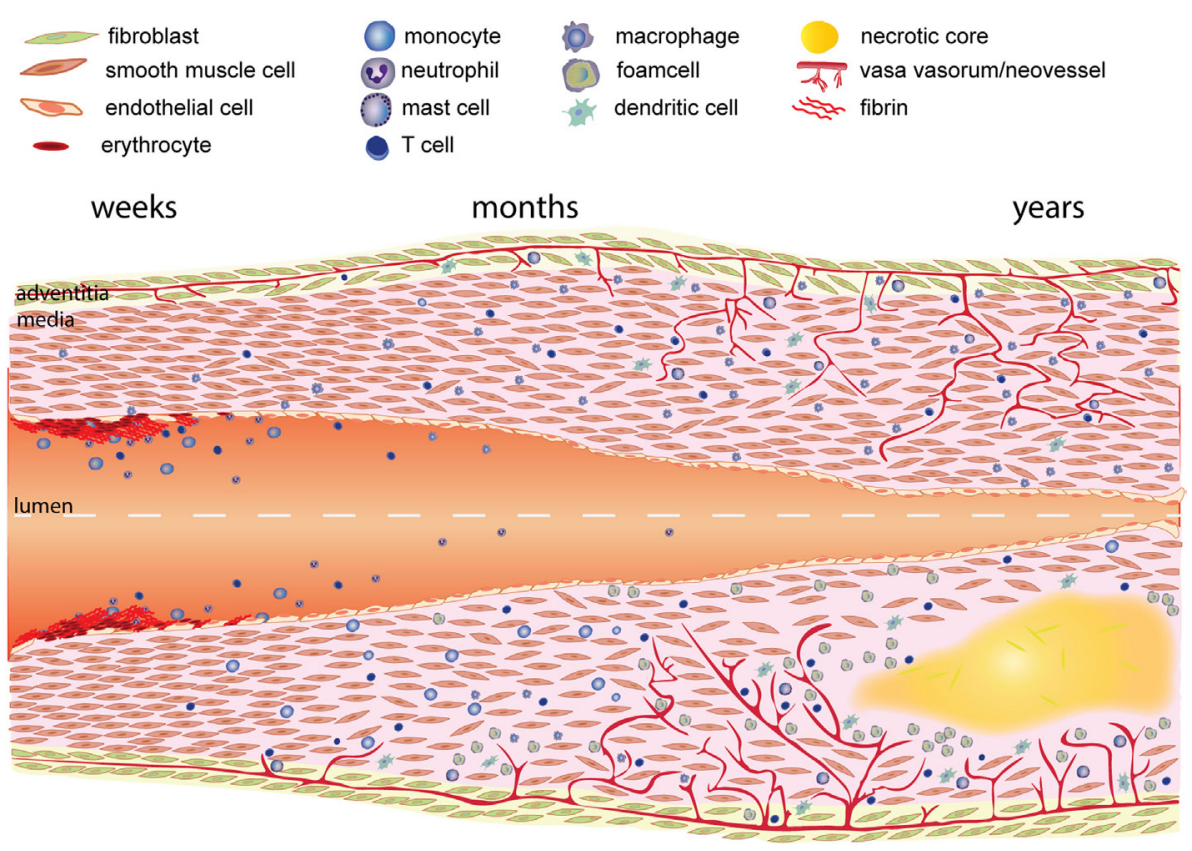

FIGURE 2 | Time course of vein graft development. As a result of the vein graft procedure the endothelial layer is damaged resulting in coverage of the luminal surface by fibrin. White blood cells (neutrophils, monocytes, and lymphocytes) attach and infiltrate the fibrin layer and intima. Next activated smooth muscle cells in the media and fibroblasts in the adventitia are and start migrating toward the intima, forming the intimal hyperplasia. Migration and proliferation of smooth muscle cells is enhanced by growth factors and cytokines released by cells in the vessel wall, and especially inflammatory cells. Growth factors and cytokines also induce extracellular matrix deposition, resulting in further growth of the intimal hyperplasia. The lower part of the figure describes the process of vein graft remodeling as it occurs under atherosclerotic conditions (lower part). Typically macrophages in the vessel wall engulf lipids and become foam cells. Subsequently a necrotic core is formed by dying cells and cholesterol depositions. Hypoxia in the vessel wall induces the growth of plaque neovessels.

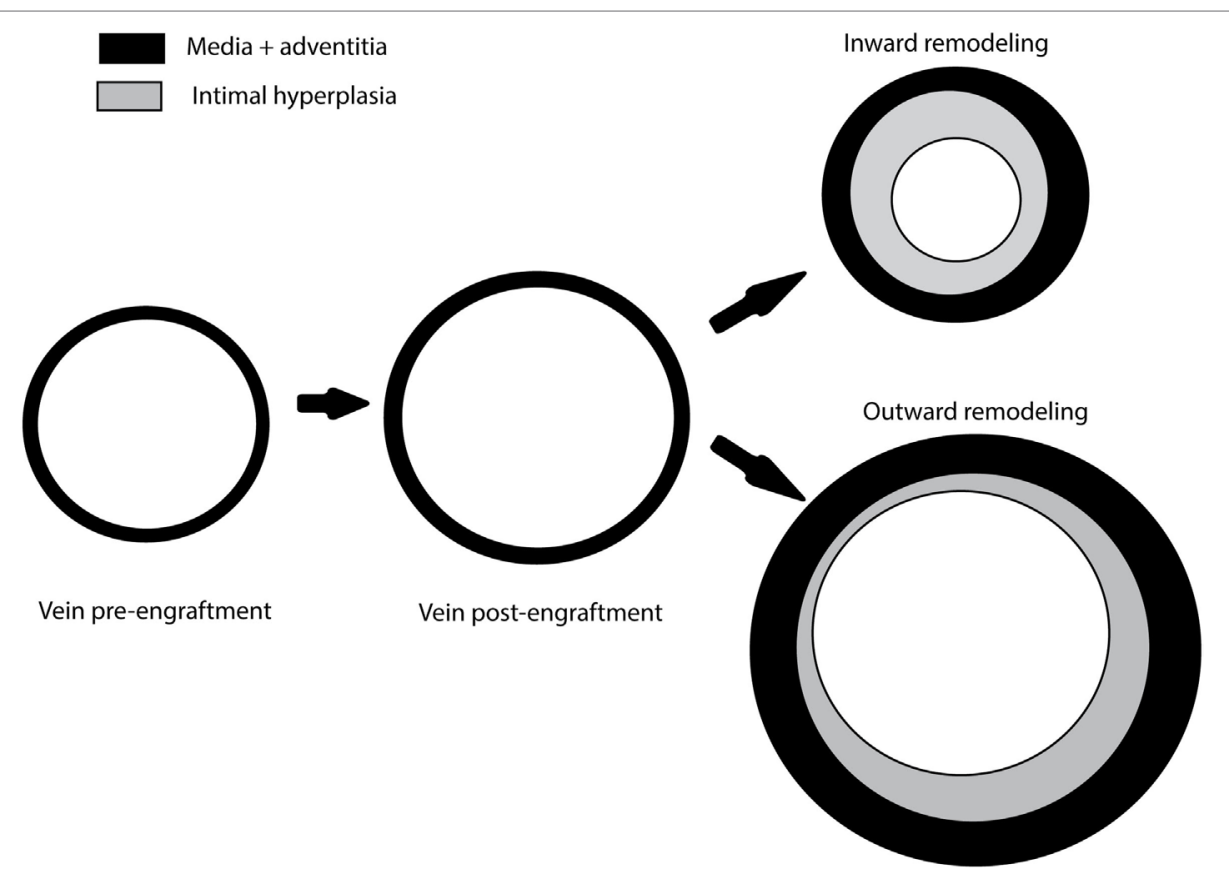

FIGURE 3 | Vein graft remodeling. Damage caused by graft handling and distension during the high-pressure check for leakage as well as implantation in the high blood pressure surrounding of the arterial circulation results in distention of the venous graft. Depending on local and systemic influences like inflammatory factors, this can result in inward remodeling characterized by intimal hyperplasia and a reduced lumen or outward remodeling characterized by moderate intimal hyperplasia and an increased lumen. 
conditions, uptake of lipids cause macrophages to turn into foam cells. Macrophage apoptosis leading to necrotic core formation and intraplaque hemorrhage further accelerates the process of VGD by formation of atherosclerotic lesions with an unstable phenotype (1). These accelerated atherosclerotic lesions in the vein grafts represent an end stage in vein graft remodeling which cause long-term (>2 years) vein graft failure $(8,24)$.

\section{CONTRIBUTION OF VESSEL WALL CONSTITUTIONS TO VGD}

\section{Endothelial Cells}

One of the first critical events that a vein has to withstand is a period of ischemia followed by reperfusion during and directly after surgery. In addition graft handling also causes damage to the grafts as well as distension that occurs during the high-pressure check for leakage (1). This leads to increased oxidative stress and cytotoxic activation, which on its turn results in endothelial cell loss $(25,26)$. Remaining endothelial cells can become apoptotic, damaged, or activated, as shown by expression of ICAM 1, VCAM1, and selectins (27-29). Damaged endothelium shows impaired vasorelaxation as a result of reduced endothelial nitric oxide synthase and NO production (30). The increase in oxidative stress and damage to the endothelium is in particularly seen in vein grafts compared to arterial graft $(31,32)$.

Following endothelial denudation, the ECM components underneath the endothelium such as collagen, elastin, and proteoglycans become exposed and can trigger coagulation processes leading to fibrin deposition on the luminal surface (33). Fibrin formation and fibrin resolution is tightly regulated by thrombosis and fibrinolysis.

Re-endothelialization begins rapidly after the initial damage. Proliferating endothelial cells are observed within the first week after vein graft surgery in experimental models resulting in a nearly intact endothelial lining 4 weeks after the surgery $(27,28$, $33,34)$. The duration of the re-endothelialization process in humans is not exactly known but it is likely that this takes somewhat more time. The endothelium-dependent relaxation as observed in human vein grafts, indicates that the grafts have seemingly functional endothelial cells (35). It is unknown whether graft endothelial cells in humans originate from the graft, the adjacent arterial tissue or from the circulation progenitor cells or a combination thereof. In a murine vein graft model it was shown that endothelial cell originate primarily from host vasculature instead of the donor vein (36). Interestingly, in humans allografts both host derived and donor derived endothelial cells were found (37).

Both circulating and local (adventitial) progenitor cells have been shown to contribute to re-endothelialization (38-40). Inducible nitric oxide synthase enhances endothelial progenitor cell attachment and differentiation (41). Homing of these progenitor cells is directed by inflammatory-type macrophages and is most probably integrin $\beta 3$ dependent $(42,43)$.

Despite the fact that enhancement of re-endothelialization is beneficial in preventing VGD in preclinical studies, no effective therapeutic approaches exist to facilitate this process (1). Therefore, a potential future therapeutic target in which the inflammatory reaction may play a role could be the promotion of endothelial progenitor cell homing to the damaged endothelium in the grafts.

\section{Smooth Muscle Cells}

Proliferation and migration of SMCs are key elements in intimal hyperplasia formation. During harvesting and engraftment, SMCs within the vein graft are exposed to ischemia resulting in SMC apoptosis $(25,44,45)$. Remaining SMCs can change from a quiescent contractile phenotype to a dedifferentiated, proliferating synthetic phenotype. These cells can migrate from the media to the intima of the graft. Alternatively SMCs may migrate from the anastomosed artery toward the intima of the graft $(46,47)$. Both arterial and venous SMC have been shown to contribute to the intimal hyperplasia in vein grafts $(48,49)$. Interestingly, after engrafting of a venous segment in the arterial circulation venous marker Ephrin B4 was decreased pointing toward a loss of venous identity during arterialization (50).

Smooth muscle cells in vein grafts express different growth factors such as PDGF, TGF- $\beta$, vascular endothelial growth factor, and endothelin-1, which are major stimulators of intimal hyperplasia formation (51-54). Targeting of growth factors or their receptors in preclinical models interfere with this intimal growth (55-58). Arterial and venous grafts display a different pattern of expression of growth factors and signal transduction pathway factors $(45,48,59)$, which might contribute to the lower patency rates of venous grafts. Venous SMCs show enhanced MAPK dependent proliferation in comparison to arterial SMCs (60). SMCs and especially activated SMCs produce cytokines such as tumor necrosis factor alpha ( $\mathrm{TNF} \alpha)$ and $\mathrm{C}-\mathrm{C}$ motif chemokine CCL2 (also known as MCP-1) $(61,62)$, which can increase the Rho/Rac GTPase signaling cascade leading to enhanced SMC migration and proliferation (63).

Veins possess elastin fibers but lack defined external and internal elastic lamina. Therefore, fibroblasts when migrating from the adventitia to the intima in veins encounter little barriers. These adventitial fibroblasts are highly proliferative. Adventitial fibroblasts that acquire a smooth muscle-like phenotype are known to contribute to intimal hyperplasia formation $(64,65)$.

Adventitial and bone marrow-derived progenitor cells also contribute to the thickening of the vein graft wall $(38,39$, $66,67)$. Already during vein graft surgery the bone marrow releases functional active CXCR4 ${ }^{+}$progenitor cells (68). Although a substantial portion of the bone marrow-derived cells express a SMC phenotype, they do not fully acquire the complete SMC lineage phenotype (69). Cytokine dependent activation of Stem Cell Antigen- $1^{+}$positive bone marrow-derived progenitor cells results in enhanced SMC migration and proliferation (70). Vein grafting in mice deficient in CXCR4 resulted in reduced vein graft thickening (71). Also knock down of fibroblast-specific protein-1 in bone marrow cells inhibited intimal hyperplasia (72).

\section{Extracellular Matrix}

In the initial phase after vein graft surgery exposure of components of the ECM interact with plasma components and platelets and contribute to the thrombogenic luminal surface of the vein graft. ECM components such as fibronectin, heperansulphate 
and other proteoglycans can act as DAMPs which interact with pattern recognition receptors like TLRs, thereby initiating a proinflammatory response, primarily directed by nuclear factor kappa-light-chain-enhancer of activated B cells (NF- $\mathrm{BB}$ ) (73). The ECM component hyaluronic acid is especially found in arterialized vein grafts and contributes to vein graft intimal thickening by inducing SMC proliferation (74). In the first phases of vein graft remodeling, upregulation of TGF- $\beta$ is linked to increased mRNA expression of collagen I, and collagen III $(75,76)$. In a rabbit vein graft model late stage remodeling ( $>1$ month) enhanced TGF- $\beta$ expression was observed which was accompanied by increased fibrosis and reduced matrix metalloproteinase (MMP) 2 and MMP9 activity (77). In rats inhibition of TGF- $\beta$ signaling resulted in reduced intimal hyperplasia as a result of increased MMP activity (58). The proteases that degrade collagen and other components of the ECM are highly expressed in vein grafts, especially MMP2 and MMP are extensively researched (78-81). MMPs can be secreted by both macrophages and SMC in the vessel wall, however, most interactions with the MMP system results in effects on SMC migration and proliferation and ECM build up. Gene therapeutic approaches in saphenous vein SMCs to silence expression of MMP2 and MMP9 demonstrated reduced SMC migration through a matrigel barrier (82). Moreover, in MMP9 knockout mice the lesion composition was changed due to an increase in collagen content while intimal hyperplasia was similar as in control mice after vein grafting (83). Inhibition of MMPs by the general MMP inhibitor doxycycline resulted in decreased intimal hyperplasia formation in murine vein grafts (80). Overexpression of tissue inhibitors of MMPs (TIMP) 1, 2 , and 3 in vein graft models in various experimental animals resulted in intimal hyperplasia formation due to reduced SMC migration and proliferation and inhibition of MMP activity as well as reduced infiltration and migration of inflammatory cells (84-88).

Plasmin, formed by activation of plasminogen by plasminogen activators, can contribute to activation of MMPs and can cleave ECM components, such as laminin and fibronectin. These ECM degradation products subsequently can bind to pattern recognition receptors (89). Failed human vein grafts demonstrated an increased expression of members of the plasminogen activation system $(90,91)$. The plasminogen activation system consists of two main PAs, urokinase-type PA (uPA) and tissue-type PA (tPA). uPA is essential in extracellular proteolysis, cell migration, and matrix remodeling, while tPA is mainly involved in fibrinolysis (92). In porcine vein grafts overexpression of tPA reduced early vein graft thrombosis (93). Adenovirus mediated overexpression in human saphenous explants of a hybrid protein consisting of the receptor-binding amino terminal fragment (ATF) of urokinase and bovine pancreas trypsin inhibitor (BPTI) was able to potently reduce intimal hyperplasia formation (94). A hybrid protein consisting of TIMP1 and the aforementioned ATF was constructed to inhibit MMP activity locally at the cell surface (95). This construct reduced vein graft thickening and preserved the luminal area (96). A third protein was constructed by combining the three constructs resulting in TIMP1.ATF.BPTI that was capable of inhibiting both plasmin and MMP activity at the cell surface, which effectively reduced vein graft intimal hyperplasia and outward remodeling (97). Plasminogen activator inhibitor 1 (PAI1), another plasminogen activator, showed also clear effects on vein graft remodeling. PAI1-deficient mice showed enhanced intimal hyperplasia due to increased thrombin activity (98).

\section{INFLAMMATION}

The immune system plays an important role during all phases in vein graft development $(99,100)$. Immediately after surgery DAMPs are released which via binding to the TLRs activate the cells in the vessel wall resulting in the release of growth factors and cytokines. DAMPS can also activate platelets and thus enhance, due to the platelet expressed adhesion molecules P- and E-selectin, the attachment of circulating leukocytes and subsequent infiltration into the vessel wall (101). Neutrophils are mainly detected on the de-endothelialized lumen within the fibrin layer that is formed there (102). Neutrophils are phagocytes that also produce MMP2 and MMP9, as well as other proteases and a wide array of growth factors with which they can influence neighboring cells in the vessel wall (103). Monocytes enter the vein graft via adhesion to the luminal surface or via neovessels in the adventitia (104). Macrophage colony stimulating factor turns these invasive monocytes into macrophages. Macrophages represent the vast majority of inflammatory cells in the vein graft wall and by producing and releasing various cytokines and growth factors influence intimal hyperplasia formation (105). Direct or indirect inhibition of macrophages, by targeting macrophage activating factors have been shown to be successful strategies in preventing the inflammatory response and VGD $(61,106,107)$. In addition, various types of inflammatory cells seem to be derived from the adventitia, which consists of loose connective tissue, small neovessels, and nerves. Dendritic cells, mast cells, natural killer $(\mathrm{NK})$ cells, $\mathrm{T}$, and B cells are primarily found in the adventitia (108).

The late phase of vein graft development is characterized by oxidized low-density lipoprotein (ox-LDL) retention and subsequent lipid accumulation $(24,34)$. Phosphorylcholine is one of the neoantigens exposed by LDL oxidation that can elicit an immune response. Passive immunization with anti-phosphorylcholine antibodies resulted in a reduced inflammatory phenotype which prevents vein graft atherosclerosis in a hypercholesterolemic murine model (109). Interestingly, low levels of natural antibodies against phosphorylcholine in humans are associated with VGD (110). Phosphorylcholine is one of the many ligands for TLRs, like the DAMPs that are expressed upon damage to the vein graft wall. TLRs are central in the induction of inflammatory responses in vascular cell types, and can activate inflammatory cells of both the innate and adaptive immune system $(1,73,111)$. TLR activation generally lead via the myeloid differentiation primary response protein 88 (MyD88) pathway, to activation of $\mathrm{NF}-\kappa \mathrm{B}$ and results in induction of cytokines (112). In general, proinflammatory cytokines stimulate vein graft remodeling (99, 113-115). These cytokines activate inflammatory cells but also stimulate SMC migration and proliferation as well as activation of endothelial cells.

NF- $\kappa \mathrm{B}$ is one of the most important transcription factors for promotion of inflammatory responses in vein graft remodeling (1). 
Inhibition of NF- $\mathrm{NB}$ resulted in reduced inflammatory responses and attenuation of vein graft thickening in experimental models (116-118). The downstream NF- $\kappa \mathrm{B}$ targets CCL2 and TNF $\alpha$ both have been linked to VGD $(119,120)$. Overexpression of a dominant negative form of CCL2 reduced accelerated atherosclerosis and monocyte invasion in vein grafts in mice on a hypercholesterolemic diet (61). Furthermore, lentivirus mediated overexpression of a shRNA silencing the CCL2 receptor, CCR2, inhibited SMC proliferation and migration and reduced vein graft thickening (121). TNF $\alpha$ is one of the early up-regulated factors in vein graft development. This induction is thought to be a result of the early activation of TLRs. In TNF receptor-1-deficient mice, reduced CCL2 expression and SMC proliferation resulted in reduced vein graft intimal hyperplasia (122). Furthermore, TNF receptor-2-deficient mice also showed reduced vein graft thickening as a result of endothelial cell apoptosis (123). An overview of the various inflammatory factors that are linked to VGD is given in Table $\mathbf{1}$.

\section{IMMUNE MODULATION}

\section{Toll-Like Receptors}

As indicated above, TLRs play a crucial role in the early inflammatory triggers that initiate vein graft remodeling. Among the first mediators of inflammation in vein grafts are DAMPs such as aggrecan and heat shock proteins $(135,136)$. Endogenous DAMPs activate TLRs that are expressed by cells in the vein graft wall such as endothelial cells and SMCs $(1,73,137)$. Exaggerating

TABLE 1 | Inflammatory factors involved in vein graft disease (VGD).

\begin{tabular}{|c|c|c|c|}
\hline Target/treatment & $\begin{array}{l}\text { Effect on } \\
\text { VGD }\end{array}$ & $\begin{array}{l}\text { Experimental } \\
\text { animal }\end{array}$ & Reference \\
\hline $\begin{array}{l}\text { Notch ligand delta- } \\
\text { like } 4\end{array}$ & + & Mouse & Koga et al. (107) \\
\hline Dexamethasone & - & Mouse & Schepers et al. (124) \\
\hline Annexin A5 & - & Mouse & Ewing et al. (125) \\
\hline $\begin{array}{l}\text { Phosphorylcholine } \\
\text { antibodies }\end{array}$ & - & Mouse & Faria-Neto et al. (109) \\
\hline$\| 1$ & + & Mouse & Yu et al. (115) \\
\hline$N F-\kappa B$ & + & Dog & Shintani et al. (116) \\
\hline$N F-\kappa B$ & + & Rabbit & Miyake et al. (117) \\
\hline$N F-\kappa B$ & + & Rat & Meng et al. (118) \\
\hline MCP-1/CCL2 & + & Dog & Tatewaki et al. (119) \\
\hline MCP-1/CCL2 & + & Mouse & Fu et al. (120) \\
\hline MCP-1/CCL2 & + & Mouse & Schepers et al. (61) \\
\hline CCR2 & + & Mouse & Eefting et al. (121) \\
\hline TNF-R1 & + & Mouse & Zhang et al. (122) \\
\hline TNF-R2 & - & Mouse & Zhang et al. (123) \\
\hline TLR4 & + & Mouse & Karper et al. (73) \\
\hline TLR4 & + & Mouse & Nguyen et al. (126) \\
\hline RP105 & + & Mouse & Wezel et al. (127) \\
\hline C1 inhibitor & - & Mouse & Krijnen et al. (128) \\
\hline C3 & + & Mouse & Schepers et al. (129) \\
\hline $\mathrm{C5a}$ & + & Mouse & de Vries et al. (130) \\
\hline C5a & + & Mouse & Wezel et al. (131) \\
\hline Mast cell & + & Mouse & de Vries et al. (130) \\
\hline Mast cell & + & Mouse & Wu et al. (132) \\
\hline Natural killer cells & + & Mouse & de Vries et al. (133) \\
\hline Interferon regulating & - & Mouse & Simons et al. (134) \\
\hline
\end{tabular}

this response by applying low dose lipopolysaccharide, a strong TLR4 ligand, topically on the vein graft resulted in a strong induction of the inflammatory response and increased intimal thickening (126). Blocking TLR4 in a murine vein graft model, either by genetic deletion or by lentiviral mediated local shRNA silencing, reduced outward remodeling and intimal hyperplasia formation, due to the suppressed inflammatory responses (73). Ligation of the carotid artery in TLR4-deficient mice showed outward remodeling without intimal hyperplasia formation in the non-ligated artery (111). It is therefore suggested that TLR4 affects hemodynamic adaptations and vascular remodeling independently of intimal hyperplasia formation (1). Inhibition of the TLR4 homolog radioprotective 105 aggravated intimal hyperplasia formation in vein graft by increased proinflammatory macrophage proliferation and enhanced SMC migration and proliferation (127). Comparable results were found in vascular remodeling models for restenosis and arteriovenous fistula $(138,139)$. Whereas in atherosclerosis models a reduction of atherosclerosis could be observed due to the specific function of RP105 on B cells and inhibition of CCR2 dependent macrophage migration $(140,141)$. Next to the role of TLRs, other components of the innate immune system such as members of the complement cascade are linked to vein graft remodeling.

\section{Complement System}

The complement cascade is a large family of acute response effector and regulatory proteins that is a prominent member of the innate immunity. Vein graft surgery activates the complement system and continues during the vein graft remodeling process since complement factors are present and produced locally in the vein graft wall (129). Inhibition of the key complement factor C3 resulted in reduced intimal hyperplasia by reducing inflammatory cell influx in murine vein grafts (129). Clinh a natural occurring protease inhibitor of the serpin family and alternative pathway component prevented endothelial cell damage in ex vivo perfused human saphenous vein segments and reduced vein graft intimal hyperplasia in a murine model (128). In the same in vitro perfusion model it was shown that the endogenous complement inhibitor, the C4b-binding protein, was present in the saphenous vein wall and has protective mechanisms to cellular stress and inflammation (142). C5a is one of the major biologically active components of the complement cascade downstream of $\mathrm{C} 3$ and exerts its function including chemotaxis of monocytes and mast cells mainly via the canonical C5a receptor. Local application of $\mathrm{C} 5 \mathrm{a}$ on the vein graft resulted in increased intimal hyperplasia in a mast cell dependent manner (130). Furthermore, acute application of C5a results in enhancement of plaque disruption (131). Inhibition of complement factors seems to be a very promising strategy for preventing VGD in humans. Most interestingly, the mortality in high-risk surgical patients undergoing CABG surgery was reduced by intravenous administration of an antibody against complement factor C5 (pexelizumab) (143).

\section{Mast Cells}

Mast cells are large granular cells that upon activation by $\operatorname{IgE}$, cytokines (TNF $\alpha, \mathrm{IL} 1)$ and complement factors release granules containing tryptase, chymase, and histamine (144). Vein grafts 
are rapidly repopulated with mast cells; it should be noted that resting as well as activated mast cells can be found mainly in the perivascular region of vein grafts but not so much in the vessel wall itself $(130,132,145)$. Mast cell-deficient mice showed a reduction in intimal hyperplasia in vein grafts, as well as a general reduction of vascular inflammation $(130,132)$. Moreover, activation of mast cells locally resulted in more unstable lesions and features of plaque rupture (130). The strong effect of mast cells on lesion instability is also seen in native atherosclerosis (146). Remarkably, in these lesions, most mast cells were found in the close vicinity of plaque neovascularization (146).

\section{NK Cells}

Also present in the perivascular region of vein grafts and especially in the adventitia are NK cells (133). Upon activation NK cells secrete lytic granules containing perforin and granzymes and various proinflammatory cytokines (147). The NK cell function is reduced in BALB/C mice due to the lack of crucial NK cell genes of the Ly49 receptor family. When vein graft surgery was performed in $\mathrm{BALB} / \mathrm{c}$ mice congenic for the $\mathrm{C} 57 \mathrm{BL} / 6 \mathrm{NK}$ gene region, these mice displayed a similar degree of intimal hyperplasia as C57BL/6 mice, while BALB/c mice showed significantly less vein graft remodeling and intimal hyperplasia (133). Furthermore, a decrease in inflammatory cells and interferon- $\gamma$ expression in the vein graft wall was observed.

\section{Dendritic Cells}

Dendritic cells, originating from Ly-6C ${ }^{\text {lo }}$ monocytes, are found in all layers of the vein graft and colocalize with $\mathrm{T}$ cells as antigen presenting cells (148). In vein grafts dendritic cells are capable of triggering T cells by costimulation of CD40 (149).

The involvement of adaptive immunity members in VGD is less established than the role of the innate immunity. The participation of the adaptive immune system in vascular diseases is clear and the role in atherosclerosis and restenosis is well described (150).

\section{T and B Cells}

$\mathrm{T}$ and $\mathrm{B}$ cells have been identified in vein graft lesions, however, no further characterization of subtypes are performed $(37,151)$. It has been shown that $\mathrm{T}$ cells are capable of proliferation in vein grafts (152). Furthermore, interaction between dendritic cells and $\mathrm{T}$ cells in a CD40 dependent manner have been observed in vein grafts (149). However, little is known about the exact function and role of T cells in the pathophysiology of VGD. In a recent study, we demonstrated that downstream TLR signaling via interferon regulatory factor (IRF) 3 and 7 results in a protective effect on vein graft remodeling. This is particularly of interest since IRF3 and IRF7 activation leads to expression of type 1 interferons, that are subsequently involved in the activation of CD4 and $\mathrm{CD}^{+}$ $\mathrm{T}$ cells (134). Further studies to investigate the role of (subtypes) of $\mathrm{T}$ as well as B cells in VGD are definitely needed.

\section{PERIVASCULAR ADIPOSE TISSUE (PVAT)}

Most blood vessels, including the saphenous vein, are surrounded by PVAT. In the last decades the vasoactive role of PVAT and adipokines derived from PVAT on vascular function are more and more appreciated (153). PVAT harbors numerous amounts of inflammatory cells. Damage to PVAT results in an inflammatory response driven by adipocyte-derived factors such as resistin, leptin, or the cytokines IL-6, TNF- $\alpha$, and CCL2 (154). Protective effects of adiponectin on NADPH oxidase, superoxide production and NO bioavailability in the vessel wall are reduced after PVAT damage (155). The "no touch" technique of saphenous vein harvesting is in part based on the beneficial effects of preservation of PVAT and PVAT derived leptin $(155,156)$. Interestingly, PVAT surrounding different blood vessels differs in its response to injury. Different responses are found between PVAT surrounding saphenous veins and internal mammary arteries (157) but also between internal mammary arteries and coronary arteries (158), pointing to a cause of the encouraging patency rates of internal mammary arteries.

\section{ACCELERATED ATHEROSCLEROSIS AND LATE STAGE FAILURE}

Comparable to native atherosclerosis, hypercholesterolemia, an import driver of VGD and lipid burden, is clearly associated with vein graft age (159). Analysis of human vein grafts obtained at autopsy has shown that coronary vein grafts undergo rapid atherosclerotic lesion development (24). Lesions in coronary vein graft differ from native lesions in having a more concentric and diffuse appearance. Furthermore, the tendency to rupture and occlude due to thrombosis is very high in these vein grafts (8). Especially, older vein grafts ( $>2$ years) fail most frequently due to accelerated atherosclerosis and rupture of lesions $(8,160$, 161). Coronary bypass graft occlusion is clearly associated with presence of necrotic core, calcification and negative remodeling (162). Peripheral vein grafts probably suffer less from accelerated atherosclerosis, since these lesions mostly consist of SMCs (163). Occlusion of peripheral vein grafts is frequently linked to high rates of circulating inflammatory cells (100). Circulating inflammatory cells are now being studied as predictors for VGD; both ratios of platelet-monocyte reactivity or lymphocytes-tomonocytes ratios show correlations with VGD $(100,164)$.

Foam cell formation is already observed in one year old vein grafts. This is followed by necrotic core development between 2 and 5 years after surgery. Intraplaque hemorrhage, most likely originating from leaky angiogenic neovessels in the lesion is also observed in these advanced lesions (24). Plaque angiogenesis and intraplaque hemorrhage are important causes of plaque destabilization and rupture (165). In vein grafts in hypercholesterolemic mice various features linked to late phase graft failure are observed, including angiogenic neovessels, intraplaque hemorrhage, necrotic cores and rupture $(1,88)$. Especially the presence of plaque neovessels and intraplaque hemorrhage in this model are interesting, since this is a rare observation in atherosclerotic experimental murine models. Improved lesion stability and decreased plaque rupture could be achieved by up regulation of the MMP inhibitor TIMP-1 (88). Targeting inflammatory factors such as annexin A5, mast cells, complement factors and TLRs are effective strategies to not only inhibit intimal hyperplasia 
formation and accelerated atherosclerosis but also to alter plaque composition and reduce plaque rupture $(125,127,130,131)$.

\section{CLINICAL PHARMACOLOGICAL AND SURGICAL INTERVENTIONAL STRATEGIES}

Platelet activation and thrombin production are key triggers of early vein graft failure. Antiplatelet therapy starting directly after surgery to prevent early vein graft thrombosis is recommended for both CAD and PAOD patients. Aspirin treatment alone or dual antiplatelet (aspirin and clopidogrel) treatment have been shown to be effective in preventing graft occlusion $(166,167)$. In both Europe and USA, antiplatelet therapy is recommended to be continued until at least 3 months after the surgery and in some cases indefinitely $(4,17)$.

Comparable to native atherosclerosis statins are included in the standard of care for patients undergoing vein graft surgery. The mode of actions of statins is primarily cholesterol lowering by inhibiting HMG-CoA reductase but other mechanisms are also described. Statins can improve endothelial function, prevent proliferation of SMCs and decrease activation of macrophages $(168,169)$. Statin therapy has been proven to prevent vein graft stenosis in both coronary and peripheral grafts (170-172).

A new therapy to prevent VGD is the use of an extravascular support. The extravascular support functions as a protective outer layer of the vein graft, thereby reducing wall tension, activation and stretching of SMCs and endothelial cells (173). Promising results are obtained in in vitro and experimental studies (174-177). The recently reported positive preliminary clinical results from a study by Ferrari et al. using an external mesh

\section{REFERENCES}

1. de Vries MR, Simons KH, Jukema JW, Braun J, Quax PH. Vein graft failure: from pathophysiology to clinical outcomes. Nat Rev Cardiol (2016) 13(8):451-70. doi:10.1038/nrcardio.2016.76

2. Weintraub WS, Grau-Sepulveda MV, Weiss JM, O'Brien SM, Peterson ED, Kolm P, et al. Comparative effectiveness of revascularization strategies. N Engl J Med (2012) 366(16):1467-76. doi:10.1056/NEJMoa1110717

3. Deb S, Wijeysundera HC, Ko DT, Tsubota H, Hill S, Fremes SE. Coronary artery bypass graft surgery vs percutaneous interventions in coronary revascularization: a systematic review. JAMA (2013) 310(19):2086-95. doi:10.1001/jama.2013.281718

4. Windecker S, Kolh P, Alfonso F, Collet JP, Cremer J, Falk V, et al. 2014 ESC/EACTS Guidelines on myocardial revascularization: the Task Force on Myocardial Revascularization of the European Society of Cardiology (ESC) and the European Association for Cardio-Thoracic Surgery (EACTS) developed with the special contribution of the European Association of Percutaneous Cardiovascular Interventions (EAPCI). Eur Heart J (2014) 35(37):2541-619. doi:10.1093/eurheartj/ehu278

5. Goldman S, Zadina K, Moritz T, Ovitt T, Sethi G, Copeland JG, et al. Longterm patency of saphenous vein and left internal mammary artery grafts after coronary artery bypass surgery: results from a Department of Veterans Affairs Cooperative Study. J Am Coll Cardiol (2004) 44(11):2149-56. doi:10.1016/j. jacc.2004.08.064

6. Goldman S, Sethi GK, Holman W, Thai H, McFalls E, Ward HB, et al. Radial artery grafts vs saphenous vein grafts in coronary artery bypass surgery: a randomized trial. JAMA (2011) 305(2):167-74. doi:10.1001/jama. 2010.1976 demonstrate the possibility to improve long-term graft durability (178). The VEST trial showed an improvement in lumen uniformity after external stenting 1 year after CABG surgery in comparison to non-stented vein grafts in the same patients $(173,179,180)$. Further elaboration on these studies is needed to solidify the concept of extravascular support on graft patency.

\section{CONCLUSION}

The use of vein grafts as a revascularization strategy is still necessary despite the unfavorable patency outcomes. Constrictive remodeling, intimal hyperplasia formation, and unstable atherosclerotic lesions are the main causes of VGD in both coronary and peripheral vein grafts. Histopathological studies of human vein grafts and experimental vein graft models have demonstrated that inflammatory components, especially those from the innate immune system, are crucial in all stages of vein graft development. Additional studies are required to prevent VGD and test new strategies for the treatment of vein grafts. Targeting inflammation either in a broad form or in a very specific has great potential as revascularization strategy for failing grafts.

\section{AUTHOR CONTRIBUTIONS}

MV and PQ designed and wrote the manuscript.

\section{FUNDING}

This work was supported by a grant from the European union, Horizon 2020 MSCA joint doctoral project, MOGLYNET (project 675527).

7. Owens CD. Adaptive changes in autogenous vein grafts for arterial reconstruction: clinical implications. J Vasc Surg (2010) 51(3):736-46. doi:10.1016/j.jvs.2009.07.102

8. Yahagi K, Kolodgie FD, Otsuka F, Finn AV, Davis HR, Joner M, et al. Pathophysiology of native coronary, vein graft, and in-stent atherosclerosis. Nat Rev Cardiol (2015) 13(2):79-98. doi:10.1038/nrcardio.2015.164

9. Carrel T, Winkler B. Current trends in selection of conduits for coronary artery bypass grafting. Gen Thorac Cardiovasc Surg (2017) 65(10):549-56. doi:10.1007/s11748-017-0807-8

10. Kulik A, Ruel M. Statins and coronary artery bypass graft surgery: preoperative and postoperative efficacy and safety. Expert Opin Drug Saf (2009) 8(5):559-71. doi:10.1517/14740330903188413

11. Monahan TS, Owens CD. Risk factors for lower-extremity vein graft failure. Semin Vasc Surg (2009) 22(4):216-26. doi:10.1053/j.semvascsurg. 2009.10.003

12. Hess CN, Lopes RD, Gibson CM, Hager R, Wojdyla DM, Englum BR, et al. Saphenous vein graft failure after coronary artery bypass surgery: insights from PREVENT IV. Circulation (2014) 130(17):1445-51. doi:10.1161/ CIRCULATIONAHA.113.008193

13. Efird JT, O’Neal WT, Gouge CA, Kindell LC, Kennedy WL, Bolin P Jr, et al. Implications of hemodialysis in patients undergoing coronary artery bypass grafting. Int J Cardiovasc Res (2013) 2(6):1-16. doi:10.4172/2324-8602.1000154

14. Yanagawa B, Algarni KD, Singh SK, Deb S, Vincent J, Elituv R, et al. Clinical, biochemical, and genetic predictors of coronary artery bypass graft failure. J Thorac Cardiovasc Surg (2014) 148(2):515-20. doi:10.1016/j. jtcvs.2013.10.011

15. Samano N, Geijer H, Liden M, Fremes S, Bodin L, Souza D. The no-touch saphenous vein for coronary artery bypass grafting maintains a patency, 
after 16 years, comparable to the left internal thoracic artery: a randomized trial. J Thorac Cardiovasc Surg (2015) 150(4):880-8. doi:10.1016/j. jtcvs.2015.07.027

16. Tendera M, Aboyans V, Bartelink ML, Baumgartner I, Clement D, Collet JP, et al. ESC guidelines on the diagnosis and treatment of peripheral artery diseases: document covering atherosclerotic disease of extracranial carotid and vertebral, mesenteric, renal, upper and lower extremity arteries: the Task Force on the Diagnosis and Treatment of Peripheral Artery Diseases of the European Society of Cardiology (ESC). Eur Heart J (2011) 32(22):2851-906. doi:10.1093/eurheartj/ehr211

17. Hillis LD, Smith PK, Anderson JL, Bittl JA, Bridges CR, Byrne JG, et al. 2011 ACCF/AHA guideline for coronary artery bypass graft surgery: a report of the American College of Cardiology Foundation/American Heart Association Task Force on Practice Guidelines. Circulation (2011) 124(23):e652-735. doi:10.1161/CIR.0b013e31823c074e

18. Anderson JL, Halperin JL, Albert NM, Bozkurt B, Brindis RG, Curtis LH, et al. Management of patients with peripheral artery disease (compilation of 2005 and 2011 ACCF/AHA guideline recommendations): a report of the American College of Cardiology Foundation/American Heart Association Task Force on Practice Guidelines. Circulation (2013) 127(13):1425-43. doi:10.1161/CIR.0b013e31828b82aa

19. Ridker PM, Everett BM, Thuren T, MacFadyen JG, Chang WH, Ballantyne C, et al. Antiinflammatory therapy with canakinumab for atherosclerotic disease. N Engl J Med (2017) 377(12):1119-31. doi:10.1056/NEJMoa1707914

20. Dobrin PB, Littooy FN, Endean ED. Mechanical factors predisposing to intimal hyperplasia and medial thickening in autogenous vein grafts. Surgery (1989) 105(3):393-400.

21. Walts AE, Fishbein MC, Matloff JM. Thrombosed, ruptured atheromatous plaques in saphenous vein coronary artery bypass grafts: ten years' experience. Am Heart J (1987) 114(4 Pt 1):718-23. doi:10.1016/0002-8703(87)90780-0

22. Motwani JG, Topol EJ. Aortocoronary saphenous vein graft disease: pathogenesis, predisposition, and prevention. Circulation (1998) 97(9):916-31. doi:10.1161/01.CIR.97.9.916

23. OwensCD, RybickiFJ,WakeN,Schanzer A,MitsourasD, Gerhard-HermanMD, et al. Early remodeling of lower extremity vein grafts: inflammation influences biomechanical adaptation. J Vasc Surg (2008) 47(6):1235-42. doi:10.1016/j. jvs.2008.01.009

24. Yazdani SK, Farb A, Nakano M, Vorpahl M, Ladich E, Finn AV, et al. Pathology of drug-eluting versus bare-metal stents in saphenous vein bypass graft lesions. JACC Cardiovasc Interv (2012) 5(6):666-74. doi:10.1016/j. jcin.2011.12.017

25. Westerband A, Crouse D, Richter LC, Aguirre ML, Wixon CC, James DC, et al. Vein adaptation to arterialization in an experimental model. J Vasc Surg (2001) 33(3):561-9. doi:10.1067/mva.2001.112230

26. Osgood MJ, Hocking KM, Voskresensky IV, Li FD, Komalavilas P, CheungFlynn J, et al. Surgical vein graft preparation promotes cellular dysfunction, oxidative stress, and intimal hyperplasia in human saphenous vein. $J$ Vasc $\operatorname{Surg}(2014)$ 60(1):202-11. doi:10.1016/j.jvs.2013.06.004

27. Ehsan A, Mann MJ, Dell'Acqua G, Tamura K, Braun-Dullaeus R, Dzau VJ. Endothelial healing in vein grafts: proliferative burst unimpaired by genetic therapy of neointimal disease. Circulation (2002) 105(14):1686-92. doi:10.1161/01.CIR.0000013775.02396.93

28. Borin TF, Miyakawa AA, Cardoso L, de Figueiredo BL, Goncalves GA, Krieger JE. Apoptosis, cell proliferation and modulation of cyclindependent kinase inhibitor p21(cip1) in vascular remodelling during vein arterialization in the rat. Int J Exp Pathol (2009) 90(3):328-37. doi:10.1111/j.1365-2613.2009.00648.x

29. Li FD, Sexton KW, Hocking KM, Osgood MJ, Eagle S, Cheung-Flynn J, et al. Intimal thickness associated with endothelial dysfunction in human vein grafts. J Surg Res (2013) 180(1):e55-62. doi:10.1016/j.jss.2012.06.017

30. Sugimoto M, Yamanouchi D, Komori K. Therapeutic approach against intimal hyperplasia of vein grafts through endothelial nitric oxide synthase/ nitric oxide (eNOS/NO) and the Rho/Rho-kinase pathway. Surg Today (2009) 39(6):459-65. doi:10.1007/s00595-008-3912-6

31. Shi Y, Patel S, Davenpeck KL, Niculescu R, Rodriguez E, Magno MG, et al. Oxidative stress and lipid retention in vascular grafts: comparison between venous and arterial conduits. Circulation (2001) 103(19):2408-13. doi:10.1161/01.CIR.103.19.2408
32. Komori K, Inoguchi H, Kume M, Shoji T, Furuyama T. Differences in endothelial function and morphologic modulation between canine autogenous venous and arterial grafts: endothelium and intimal thickening. Surgery (2002) 131(1 Suppl):S249-55. doi:10.1067/msy.2002.119797

33. Tseng CN, Karlof E, Chang YT, Lengquist M, Rotzius P, Berggren PO, et al. Contribution of endothelial injury and inflammation in early phase to vein graft failure: the causal factors impact on the development of intimal hyperplasia in murine models. PLoS One (2014) 9(6):e98904. doi:10.1371/ journal.pone.0098904

34. Lardenoye JH, de Vries MR, Lowik CW, Xu Q, Dhore CR, Cleutjens JP, et al. Accelerated atherosclerosis and calcification in vein grafts: a study in $\mathrm{APOE}^{\star} 3$ Leiden transgenic mice. Circ Res (2002) 91(7):577-84. doi:10.1161/01. RES.0000036901.58329.D7

35. Owens CD, Wake N, Conte MS, Gerhard-Herman M, Beckman JA. In vivo human lower extremity saphenous vein bypass grafts manifest flow mediated vasodilation. J Vasc Surg (2009) 50(5):1063-70. doi:10.1016/j.jvs.2009.06.022

36. Xu Q, Zhang Z, Davison F, Hu Y. Circulating progenitor cells regenerate endothelium of vein graft atherosclerosis, which is diminished in ApoE-deficient mice. Circ Res (2003) 93(8):e76-86. doi:10.1161/01.RES. 0000097864.24725.60

37. Johnson TR, Tomaszewski JE, Carpenter JP. Cellular repopulation of human vein allograft bypass grafts. J Vasc Surg (2000) 31(5):994-1002. doi:10.1067/ mva.2000.105676

38. Hu Y, Zhang Z, Torsney E, Afzal AR, Davison F, Metzler B, et al. Abundant progenitor cells in the adventitia contribute to atherosclerosis of vein grafts in ApoE-deficient mice. J Clin Invest (2004) 113(9):1258-65. doi:10.1172/ JCI19628

39. Diao Y, Guthrie S, Xia SL, Ouyang X, Zhang L, Xue J, et al. Long-term engraftment of bone marrow-derived cells in the intimal hyperplasia lesion of autologous vein grafts. Am J Pathol (2008) 172(3):839-48. doi:10.2353/ ajpath.2008.070840

40. Brown MA, Zhang L, Levering VW, Wu JH, Satterwhite LL, Brian L, et al. Human umbilical cord blood-derived endothelial cells reendothelialize vein grafts and prevent thrombosis. Arterioscler Thromb Vasc Biol (2010) 30(11):2150-5. doi:10.1161/ATVBAHA.110.207076

41. Mayr U, Zou Y, Zhang Z, Dietrich H, Hu Y, Xu Q. Accelerated arteriosclerosis of vein grafts in inducible NO synthase(-/-) mice is related to decreased endothelial progenitor cell repair. Circ Res (2006) 98(3):412-20. doi:10.1161/01. RES.0000201957.09227.6d

42. Wong MM, Chen Y, Margariti A, Winkler B, Campagnolo P, Potter C, et al. Macrophages control vascular stem/progenitor cell plasticity through tumor necrosis factor-alpha-mediated nuclear factor-kappaB activation. Arterioscler Thromb Vasc Biol (2014) 34(3):635-43. doi:10.1161/ATVBAHA.113.302568

43. Liang M, Wang Y, Liang A, Dong JF, Du J, Cheng J. Impaired integrin beta3 delays endothelial cell regeneration and contributes to arteriovenous graft failure in mice. Arterioscler Thromb Vasc Biol (2015) 35(3):607-15. doi:10.1161/ATVBAHA.114.305089

44. Owens CD, Wake N, Jacot JG, Gerhard-Herman M, Gaccione P, Belkin M, et al. Early biomechanical changes in lower extremity vein grafts - distinct temporal phases of remodeling and wall stiffness. J Vasc Surg (2006) 44(4):740-6. doi:10.1016/j.jvs.2006.06.005

45. Frischknecht K, Greutert H, Weisshaupt C, Kaspar M, Yang Z, Luscher TF, et al. Different vascular smooth muscle cell apoptosis in the human internal mammary artery and the saphenous vein. Implications for bypass graft disease. J Vasc Res (2006) 43(4):338-46. doi:10.1159/000093606

46. Kalra M, Miller VM. Early remodeling of saphenous vein grafts: proliferation, migration and apoptosis of adventitial and medial cells occur simultaneously with changes in graft diameter and blood flow. J Vasc Res (2000) 37(6):576-84. doi:10.1159/000054091

47. Sur S, Swier VJ, Radwan MM, Agrawal DK. Increased expression of phosphorylated polo-like kinase 1 and histone in bypass vein graft and coronary arteries following angioplasty. PLoS One (2016) 11(1):e0147937. doi:10.1371/ journal.pone.0147937

48. Yang Z, Oemar BS, Carrel T, Kipfer B, Julmy F, Luscher TF. Different proliferative properties of smooth muscle cells of human arterial and venous bypass vessels: role of PDGF receptors, mitogen-activated protein kinase, and cyclin-dependent kinase inhibitors. Circulation (1998) 97(2):181-7. doi:10.1161/01.CIR.97.2.181 
49. Hu Y, Mayr M, Metzler B, Erdel M, Davison F, Xu Q. Both donor and recipient origins of smooth muscle cells in vein graft atherosclerotic lesions. Circ Res (2002) 91(7):e13-20. doi:10.1161/01.RES.0000037090.34760.EE

50. Muto A, Yi T, Harrison KD, Davalos A, Fancher TT, Ziegler KR, et al. Eph-B4 prevents venous adaptive remodeling in the adult arterial environment. J Exp Med (2011) 208(3):561-75. doi:10.1084/jem.20101854

51. Sterpetti AV, Cucina A, Lepidi S, Randone B, Stipa F, Aromatario C, et al. Progression and regression of myointimal hyperplasia in experimental vein grafts depends on platelet-derived growth factor and basic fibroblastic growth factor production. J Vasc Surg (1996) 23(4):568-75. doi:10.1016/ S0741-5214(96)80034-6

52. Woodside KJ, Naoum JJ, Torry RJ, Xue XY, Burke AS, Levine L, et al. Altered expression of vascular endothelial growth factor and its receptors in normal saphenous vein and in arterialized and stenotic vein grafts. Am J Surg (2003) 186(5):561-8. doi:10.1016/j.amjsurg.2003.07.023

53. Friedl R, Li J, Schumacher B, Hanke H, Waltenberger J, Hannekum A, et al. Intimal hyperplasia and expression of transforming growth factor-beta 1 in saphenous veins and internal mammary arteries before coronary artery surgery. Ann Thorac Surg (2004) 78(4):1312-8. doi:10.1016/j.athoracsur. 2004.02.066

54. Jeremy JY, Shukla N, Angelini GD, Wan S. Endothelin-1 (ET-1) and vein graft failure and the therapeutic potential of ET-1 receptor antagonists. Pharmacol Res (2011) 63(6):483-9. doi:10.1016/j.phrs.2010.10.018

55. Luo Z, Asahara T, Tsurumi Y, Isner JM, Symes JF. Reduction of vein graft intimal hyperplasia and preservation of endothelium-dependent relaxation by topical vascular endothelial growth factor. J Vasc Surg (1998) 27(1):167-73. doi:10.1016/S0741-5214(98)70304-0

56. Kimura S, Egashira K, Nakano K, Iwata E, Miyagawa M, Tsujimoto H, et al. Local delivery of imatinib mesylate (STI571)-incorporated nanoparticle ex vivo suppresses vein graft neointima formation. Circulation (2008) 118 (14 Suppl):S65-70. doi:10.1161/CIRCULATIONAHA.107.740613

57. Kapur NK, Bian C, Lin E, Deming CB, Sperry JL, Hansen BS, et al. Inhibition of transforming growth factor-beta restores endothelial thromboresistance in vein grafts. J Vasc Surg (2011) 54(4):1117-23. doi:10.1016/j.jvs.2011. 04.037

58. Sun DX, Liu Z, Tan XD, Cui DX, Wang BS, Dai XW. Nanoparticle-mediated local delivery of an antisense TGF-betal construct inhibits intimal hyperplasia in autogenous vein grafts in rats. PLoS One (2012) 7(7):e41857. doi:10.1371/journal.pone.0041857

59. Turner NA, Ho S, Warburton P, O’Regan DJ, Porter KE. Smooth muscle cells cultured from human saphenous vein exhibit increased proliferation, invasion, and mitogen-activated protein kinase activation in vitro compared with paired internal mammary artery cells. J Vasc Surg (2007) 45(5):1022-8. doi:10.1016/j.jvs.2007.01.061

60. Sun Y, Kang L, Li J, Liu H, Wang Y, Wang C, et al. Advanced glycation end products impair the functions of saphenous vein but not thoracic artery smooth muscle cells through RAGE/MAPK signalling pathway in diabetes. J Cell Mol Med (2016) 20(10):1945-55. doi:10.1111/jcmm.12886

61. Schepers A, Eefting D, Bonta PI, Grimbergen JM, de Vries MR, van Weel V, et al. Anti-MCP-1 gene therapy inhibits vascular smooth muscle cells proliferation and attenuates vein graft thickening both in vitro and in vivo. Arterioscler Thromb Vasc Biol (2006) 26(9):2063-9. doi:10.1161/01. ATV.0000235694.69719.e2

62. Monraats PS, Pires NM, Schepers A, Agema WR, Boesten LS, de Vries MR, et al. Tumor necrosis factor-alpha plays an important role in restenosis development. FASEB J (2005) 19(14):1998-2004. doi:10.1096/fj.05-4634com

63. Singh NK, Janjanam J, Rao GN. p115 RhoGEF activates the Rac1 GTPase signaling cascade in MCP1 chemokine-induced vascular smooth muscle cell migration and proliferation. J Biol Chem (2017) 292(34):14080-91. doi:10.1074/jbc.M117.777896

64. Kenagy RD, Fukai N, Min SK, Jalikis F, Kohler TR, Clowes AW. Proliferative capacity of vein graft smooth muscle cells and fibroblasts in vitro correlates with graft stenosis. J Vasc Surg (2009) 49(5):1282-8. doi:10.1016/j. jvs.2008.12.020

65. Jin D, Takai S, Li Z, Sakonjo H, Otsuki Y, Shibayama Y, et al. Outside fibroblasts play a key role in the development of inner neointima after the implantation of polytetrafluoroethylene grafts. J Pharmacol Sci (2012) 119(2):139-49. doi:10.1254/jphs.11242FP
66. Zhang L, Freedman NJ, Brian L, Peppel K. Graft-extrinsic cells predominate in vein graft arterialization. Arterioscler Thromb Vasc Biol (2004) 24(3):470-6. doi:10.1161/01.ATV.0000116865.98067.31

67. Chen Y, Wong MM, Campagnolo P, Simpson R, Winkler B, Margariti A, et al. Adventitial stem cells in vein grafts display multilineage potential that contributes to neointimal formation. Arterioscler Thromb Vasc Biol (2013) 33(8):1844-51. doi:10.1161/ATVBAHA.113.300902

68. Dotsenko O, Xiao Q, Xu Q, Jahangiri M. Bone marrow resident and circulating progenitor cells in patients undergoing cardiac surgery. Ann Thorac Surg (2010) 90(6):1944-51. doi:10.1016/j.athoracsur.2010.08.033

69. Iwata H, Manabe I, Fujiu K, Yamamoto T, Takeda N, Eguchi K, et al. Bone marrow-derived cells contribute to vascular inflammation but do not differentiate into smooth muscle cell lineages. Circulation (2010) 122(20):2048-57. doi:10.1161/CIRCULATIONAHA.110.965202

70. Yu B, Wong MM, Potter CM, Simpson RM, Karamariti E, Zhang Z, et al. Vascular stem/progenitor cell migration induced by smooth muscle cell-derived chemokine (C-C motif) ligand 2 and chemokine (C-X-C motif) ligand 1 contributes to neointima formation. Stem Cells (2016) 34(9):2368-80. doi:10.1002/stem.2410

71. Zhang L, Brian L, Freedman NJ. Vein graft neointimal hyperplasia is exacerbated by CXCR4 signaling in vein graft-extrinsic cells. J Vasc Surg (2012) 56(5):1390-7. doi:10.1016/j.jvs.2012.03.254

72. Cheng J, Wang Y, Liang A, Jia L, Du J. FSP-1 silencing in bone marrow cells suppresses neointima formation in vein graft. Circ Res (2012) 110(2):230-40. doi:10.1161/CIRCRESAHA.111.246025

73. Karper JC, de Vries MR, van den Brand BT, Hoefer IE, Fischer JW, Jukema JW, et al. Toll-like receptor 4 is involved in human and mouse vein graft remodeling, and local gene silencing reduces vein graft disease in hypercholesterolemic APOE*3Leiden mice. Arterioscler Thromb Vasc Biol (2011) 31(5):1033-40. doi:10.1161/ATVBAHA.111.223271

74. van den Boom M, Sarbia M, von Wnuck LK, Mann P, Meyer-Kirchrath J, Rauch $\mathrm{BH}$, et al. Differential regulation of hyaluronic acid synthase isoforms in human saphenous vein smooth muscle cells: possible implications for vein graft stenosis. Circ Res (2006) 98(1):36-44. doi:10.1161/01. RES.0000199263.67107.c0

75. You WJ, Xiao MD, Yuan ZX. Significance of changes in transforming growth factor-beta mRNA levels in autogenous vein grafts. Chin Med J (Engl) (2004) 117(7):1060-5.

76. Wolff RA, Ryomoto M, Stark VE, Malinowski R, Tomas JJ, Stinauer MA, et al. Antisense to transforming growth factor-betal messenger RNA reduces vein graft intimal hyperplasia and monocyte chemotactic protein 1. J Vasc Surg (2005) 41(3):498-508. doi:10.1016/j.jvs.2004.12.037

77. Jiang Z, Tao M, Omalley KA, Wang D, Ozaki CK, Berceli SA. Established neointimal hyperplasia in vein grafts expands via TGF-beta-mediated progressive fibrosis. Am J Physiol Heart Circ Physiol (2009) 297(4):H1200-7. doi:10.1152/ajpheart.00268.2009

78. Berceli SA, Jiang Z, Klingman NV, Pfahnl CL, Abouhamze ZS, Frase CD, et al. Differential expression and activity of matrix metalloproteinases during flow-modulated vein graft remodeling. J Vasc Surg (2004) 39(5):1084-90. doi:10.1016/j.jvs.2003.12.031

79. Sharony R, Pintucci G, Saunders PC, Grossi EA, Baumann FG, Galloway AC, et al. Matrix metalloproteinase expression in vein grafts: role of inflammatory mediators and extracellular signal-regulated kinases-1 and -2. Am J Physiol Heart Circ Physiol (2006) 290(4):H1651-9. doi:10.1152/ajpheart. 00530.2005

80. Lardenoye JH, de Vries MR, Deckers M, van LN, Hanemaaijer R, van Bockel $\mathrm{JH}$, et al. Inhibition of intimal hyperplasia by the tetracycline derived $\mathrm{mmp}$ inhibitor doxycycline in vein graft disease in vitro and in vivo. EuroIntervention (2005) 1(2):236-43.

81. Perek B, Malinska A, Misterski M, Ostalska-Nowicka D, Zabel M, Perek A, et al. Preexisting high expression of matrix metalloproteinase-2 in tunica media of saphenous vein conduits is associated with unfavorable long-term outcomes after coronary artery bypass grafting. Biomed Res Int (2013) 2013:730721. doi:10.1155/2013/730721

82. Turner NA, Hall KT, Ball SG, Porter KE. Selective gene silencing of either MMP-2 or MMP-9 inhibits invasion of human saphenous vein smooth muscle cells. Atherosclerosis (2007) 193(1):36-43. doi:10.1016/j. atherosclerosis.2006.08.017 
83. Thomas AC, Newby AC. Effect of matrix metalloproteinase- 9 knockout on vein graft remodelling in mice. J Vasc Res (2010) 47(4):299-308. doi:10.1159/ 000265564

84. George SJ, Lloyd CT, Angelini GD, Newby AC, Baker AH. Inhibition of late vein graft neointima formation in human and porcine models by adenovirus-mediated overexpression of tissue inhibitor of metalloproteinase-3. Circulation (2000) 101(3):296-304. doi:10.1161/01.CIR.101.3.296

85. George SJ, Baker AH, Angelini GD, Newby AC. Gene transfer of tissue inhibitor of metalloproteinase-2 inhibits metalloproteinase activity and neointima formation in human saphenous veins. Gene Ther (1998) 5(11):1552-60. doi:10.1038/sj.gt.3300764

86. George SJ, Johnson JL, Angelini GD, Newby AC, Baker AH. Adenovirusmediated gene transfer of the human TIMP-1 gene inhibits smooth muscle cell migration and neointimal formation in human saphenous vein. Hum Gene Ther (1998) 9(6):867-77. doi:10.1089/hum.1998.9.6-867

87. Hu Y, Baker AH, Zou Y, Newby AC, Xu Q. Local gene transfer of tissue inhibitor of metalloproteinase-2 influences vein graft remodeling in a mouse model. Arterioscler Thromb Vasc Biol (2001) 21(8):1275-80. doi:10.1161/ hq0801.093658

88. de Vries MR, Niessen HW, Lowik CW, Hamming JF, Jukema JW, Quax PH. Plaque rupture complications in murine atherosclerotic vein grafts can be prevented by TIMP-1 overexpression. PLoS One (2012) 7(10):e47134. doi:10.1371/journal.pone.0047134

89. Fay WP, Garg N, Sunkar M. Vascular functions of the plasminogen activation system. Arterioscler Thromb Vasc Biol (2007) 27(6):1231-7. doi:10.1161/ ATVBAHA.107.140046

90. Kauhanen P, Siren V, Carpen O, Vaheri A, Lepantalo M, Lassila R. Plasminogen activator inhibitor-1 in neointima of vein grafts: its role in reduced fibrinolytic potential and graft failure. Circulation (1997) 96(6):1783-9. doi:10.1161/01. CIR.96.6.1783

91. Siren V, Kauhanen P, Carpen O, Luther M, Lepantalo M, Vaheri A, et al. Urokinase, tissue-type plasminogen activator and plasminogen activator inhibitor-1 expression in severely stenosed and occluded vein grafts with thrombosis. Blood Coagul Fibrinolysis (2003) 14(4):369-77. doi:10.1097/ 00001721-200306000-00008

92. Carmeliet P, Moons L, Herbert JM, Crawley J, Lupu F, Lijnen R, et al. Urokinase but not tissue plasminogen activator mediates arterial neointima formation in mice. Circ Res (1997) 81(5):829-39. doi:10.1161/01.RES.81.5.829

93. Thomas AC, Wyatt MJ, Newby AC. Reduction of early vein graft thrombosis by tissue plasminogen activator gene transfer. Thromb Haemost (2009) 102(1):145-52. doi:10.1160/TH08-11-0772

94. Quax PH, Lamfers ML, Lardenoye JH, Grimbergen JM, de Vries MR, Slomp J, et al. Adenoviral expression of a urokinase receptor-targeted protease inhibitor inhibits neointima formation in murine and human blood vessels. Circulation (2001) 103(4):562-9. doi:10.1161/01.CIR.103.4.562

95. Lamfers ML, Grimbergen JM, Aalders MC, Havenga MJ, de Vries MR, Huisman LG, et al. Gene transfer of the urokinase-type plasminogen activator receptor-targeted matrix metalloproteinase inhibitor TIMP-1. ATF suppresses neointima formation more efficiently than tissue inhibitor of metalloproteinase-1. Circ Res (2002) 91(10):945-52. doi:10.1161/01. RES.0000041418.51906.57

96. Eefting D, de Vries MR, Grimbergen JM, Karper JC, van Bockel JH, Quax PH. In vivo suppression of vein graft disease by nonviral, electroporationmediated, gene transfer of tissue inhibitor of metalloproteinase-1 linked to the amino terminal fragment of urokinase (TIMP-1.ATF), a cell-surface directed matrix metalloproteinase inhibitor. J Vasc Surg (2010) 51(2):429-37. doi:10.1016/j.jvs.2009.09.026

97. Eefting D, Seghers L, Grimbergen JM, de Vries MR, de Boer HC, LardenoyeJW, et al. A novel urokinase receptor-targeted inhibitor for plasmin and matrix metalloproteinases suppresses vein graft disease. Cardiovasc Res (2010) 88(2):367-75. doi:10.1093/cvr/cvq203

98. Ji Y, Strawn TL, Grunz EA, Stevenson MJ, Lohman AW, Lawrence DA, et al. Multifaceted role of plasminogen activator inhibitor-1 in regulating early remodeling of vein bypass grafts. Arterioscler Thromb Vasc Biol (2011) 31(8):1781-7. doi:10.1161/ATVBAHA.111.228767

99. Ozaki CK. Cytokines and the early vein graft: strategies to enhance durability. J Vasc Surg (2007) 45(Suppl A):A92-8. doi:10.1016/j.jvs.2007. 02.032
100. Moreno K, Murray-Wijelath J, Yagi M, Kohler T, Hatsukami T, Clowes A, et al. Circulating inflammatory cells are associated with vein graft stenosis. J Vasc Surg (2011) 54(4):1124-30. doi:10.1016/j.jvs.2011.04.039

101. Yukizane T, Okadome K, Eguchi H, Muto Y, Sugimachi K. Isotopic study of the effects of platelets on development of intimal thickening in autologous vein grafts in dogs. Br J Surg (1991) 78(3):297-302. doi:10.1002/bjs.1800780310

102. Schlitt A, Pruefer D, Buerke U, Russ M, Dahm M, Oelert H, et al. Neutrophil adherence to activated saphenous vein and mammary endothelium after graft preparation. Ann Thorac Surg (2006) 81(4):1262-8. doi:10.1016/j. athoracsur.2005.09.073

103. Drechsler M, Doring Y, Megens RT, Soehnlein O. Neutrophilic granulocytes promiscuous accelerators of atherosclerosis. Thromb Haemost (2011) 106(5):839-48. doi:10.1160/TH11-07-0501

104. Parma L, Baganha F, Quax PHA, de Vries MR. Plaque angiogenesis and intraplaque hemorrhage in atherosclerosis. Eur J Pharmacol (2017) 816:107-15. doi:10.1016/j.ejphar.2017.04.028

105. Malinska A, Perek B, Buczkowski P, Kowalska K, Ostalska-Nowicka D, Witkiewicz W, et al. CD68 expression in aortocoronary saphenous vein bypass grafts. Histochem Cell Biol (2013) 140(2):183-8. doi:10.1007/s00418012-1069-2

106. Ewing MM, Karper JC, Sampietro ML, de Vries MR, Pettersson K, Jukema JW, et al. Annexin A5 prevents post-interventional accelerated atherosclerosis development in a dose-dependent fashion in mice. Atherosclerosis (2012) 221(2):333-40. doi:10.1016/j.atherosclerosis.2012.01.037

107. Koga J, Nakano T, Dahlman JE, Figueiredo JL, Zhang H, Decano J, et al. Macrophage Notch ligand delta-like 4 promotes vein graft lesion development: implications for the treatment of vein graft failure. Arterioscler Thromb Vasc Biol (2015) 35(11):2343-53. doi:10.1161/ATVBAHA.115.305516

108. Cherian SM, Bobryshev YV, Inder SJ, Wang AY, Lord RS, Farnsworth AE. Dendritic cells in aortocoronary saphenous vein bypass grafts. Heart Lung Circ (2000) 9(1):39-42. doi:10.1046/j.1444-2892.2000.009001039.x

109. Faria-Neto JR, Chyu KY, Li X, Dimayuga PC, Ferreira C, Yano J, et al. Passive immunization with monoclonal IgM antibodies against phosphorylcholine reduces accelerated vein graft atherosclerosis in apolipoprotein E-null mice. Atherosclerosis (2006) 189(1):83-90. doi:10.1016/j. atherosclerosis.2005.11.033

110. Sobel M, Moreno KI, Yagi M, Kohler TR, Tang GL, Clowes AW, et al. Low levels of a natural IgM antibody are associated with vein graft stenosis and failure. J Vasc Surg (2013) 58(4):997-1005.e1-2. doi:10.1016/j.jvs.2013.04.042

111. HollestelleSC, deVriesMR, Van KeulenJK,SchoneveldAH,VinkA,StrijderCF, et al. Toll-like receptor 4 is involved in outward arterial remodeling. Circulation (2004) 109(3):393-8. doi:10.1161/01.CIR.0000109140.51366.72

112. Kawai T, Akira S. Toll-like receptors and their crosstalk with other innate receptors in infection and immunity. Immunity (2011) 34(5):637-50. doi:10.1016/j.immuni.2011.05.006

113. Jiang Z, Berceli SA, Pfahnl CL, Wu L, Goldman D, Tao M, et al. Wall shear modulation of cytokines in early vein grafts. J Vasc Surg (2004) 40(2):345-50. doi:10.1016/j.jvs.2004.03.048

114. Christiansen JF, Hartwig D, Bechtel JF, Kluter H, Sievers H, Schonbeck U, et al. Diseased vein grafts express elevated inflammatory cytokine levels compared with atherosclerotic coronary arteries. Ann Thorac Surg (2004) 77(5):1575-9. doi:10.1016/j.athoracsur.2003.10.107

115. Yu P, Nguyen BT, Tao M, Jiang T, Mauro CR, Wang Y, et al. Lack of interleukin-1 signaling results in perturbed early vein graft wall adaptations. Surgery (2013) 153(1):63-9. doi:10.1016/j.surg.2012.06.005

116. Shintani T, Sawa Y, Takahashi T, Matsumiya G, Matsuura N, Miyamoto Y, et al. Intraoperative transfection of vein grafts with the NFkappaB decoy in a canine aortocoronary bypass model: a strategy to attenuate intimal hyperplasia. Ann Thorac Surg (2002) 74(4):1132-7. doi:10.1016/S00034975(02)03921-8

117. Miyake T, Aoki M, Shiraya S, Tanemoto K, Ogihara T, Kaneda Y, et al. Inhibitory effects of NFkappaB decoy oligodeoxynucleotides on neointimal hyperplasia in a rabbit vein graft model. J Mol Cell Cardiol (2006) 41(3):431-40. doi:10.1016/j.yjmcc.2006.04.006

118. Meng XB, Bi XL, Zhao HL, Feng JB, Zhang JP, Song GM, et al. Small interfering RNA targeting nuclear factor kappa B to prevent vein graft stenosis in rat models. Transplant Proc (2013) 45(6):2553-8. doi:10.1016/j. transproceed.2013.03.045 
119. Tatewaki H, Egashira K, Kimura S, Nishida T, Morita S, Tominaga R. Blockade of monocyte chemoattractant protein-1 by adenoviral gene transfer inhibits experimental vein graft neointimal formation. J Vasc Surg (2007) 45(6):1236-43. doi:10.1016/j.jvs.2007.01.066

120. Fu C, Yu P, Tao M, Gupta T, Moldawer LL, Berceli SA, et al. Monocyte chemoattractant protein-1/CCR2 axis promotes vein graft neointimal hyperplasia through its signaling in graft-extrinsic cell populations. Arterioscler Thromb Vasc Biol (2012) 32(10):2418-26. doi:10.1161/ATVBAHA.112.255786

121. Eefting D, Bot I, de Vries MR, Schepers A, van Bockel JH, van Berkel TJ, et al. Local lentiviral short hairpin RNA silencing of CCR2 inhibits vein graft thickening in hypercholesterolemic apolipoprotein E3-Leiden mice. J Vasc Surg (2009) 50(1):152-60. doi:10.1016/j.jvs.2009.03.027

122. Zhang L, Peppel K, Brian L, Chien L, Freedman NJ. Vein graft neointimal hyperplasia is exacerbated by tumor necrosis factor receptor-1 signaling in graft-intrinsic cells. Arterioscler Thromb Vasc Biol (2004) 24(12):2277-83. doi:10.1161/01.ATV.0000147766.68987.0d

123. Zhang L, Sivashanmugam P, Wu JH, Brian L, Exum ST, Freedman NJ, et al. Tumor necrosis factor receptor-2 signaling attenuates vein graft neointima formation by promoting endothelial recovery. Arterioscler Thromb Vasc Biol (2008) 28(2):284-9. doi:10.1161/ATVBAHA.107.151613

124. Schepers A, Pires NM, Eefting D, de Vries MR, van Bockel JH, Quax PH. Short-term dexamethasone treatment inhibits vein graft thickening in hypercholesterolemic ApoE3Leiden transgenic mice. J Vasc Surg (2006) 43(4): 809-15. doi:10.1016/j.jvs.2005.11.019

125. Ewing MM, de Vries MR, Nordzell M, Pettersson K, de Boer HC, van Zonneveld AJ, et al. Annexin A5 therapy attenuates vascular inflammation and remodeling and improves endothelial function in mice. Arterioscler Thromb Vasc Biol (2011) 31(1):95-101. doi:10.1161/ATVBAHA.110.216747

126. Nguyen BT, Yu P, Tao M, Hao S, Jiang T, Ozaki CK. Perivascular innate immune events modulate early murine vein graft adaptations. J Vasc Surg (2012) 57(2):486-92.e2. doi:10.1016/j.jvs.2012.07.007

127. Wezel A, de Vries MR, Maassen JM, Kip P, Peters EA, Karper JC, et al. Deficiency of the TLR4 analogue RP105 aggravates vein graft disease by inducing a pro-inflammatory response. Sci Rep (2016) 6:24248. doi:10.1038/ srep24248

128. Krijnen PA, Kupreishvili K, de Vries MR, Schepers A, Stooker W, Vonk AB, et al. C1-esterase inhibitor protects against early vein graft remodeling under arterial blood pressure. Atherosclerosis (2011) 220(1):86-92. doi:10.1016/j. atherosclerosis.2011.10.021

129. Schepers A, de VriesMR, vanLeuven CJ,GrimbergenJM,Holers VM,DahaMR, et al. Inhibition of complement component C3 reduces vein graft atherosclerosis in apolipoprotein E3-Leiden transgenic mice. Circulation (2006) 114(25):2831-8. doi:10.1161/CIRCULATIONAHA.106.619502

130. de Vries MR, Wezel A, Schepers A, van Santbrink PJ, Woodruff TM, Niessen HW, et al. Complement factor C5a as mast cell activator mediates vascular remodelling in vein graft disease. Cardiovasc Res (2013) 97(2):31120. doi: $10.1093 / \mathrm{cvr} / \mathrm{cvs} 312$

131. Wezel A, de Vries MR, Lagraauw HM, Foks AC, Kuiper J, Quax PH, et al. Complement factor $\mathrm{C} 5 \mathrm{a}$ induces atherosclerotic plaque disruptions. J Cell Mol Med (2014) 18(10):2020-30. doi:10.1111/jcmm.12357

132. Wu J, Grassia G, Cambrook H, Ialenti A, MacRitchie N, Carberry J, et al. Perivascular mast cells regulate vein graft neointimal formation and remodeling. PeerJ (2015) 3:e1192. doi:10.7717/peerj.1192

133. de Vries MR, Seghers L, van BJ, Peters HA, de Jong RC, Hamming JF, et al. $\mathrm{C} 57 \mathrm{BL} / 6 \mathrm{NK}$ cell gene complex is crucially involved in vascular remodeling. J Mol Cell Cardiol (2013) 64:51-8. doi:10.1016/j.yjmcc.2013.08.009

134. Simons KH, Peters HAB, Wouter Jukema J, de Vries MR, Quax PHA. A protective role of IRF3 and IRF7 signalling downstream TLRs in the development of vein graft disease via type I interferons. J Intern Med (2017) 282:522-36. doi:10.1111/joim.12679

135. Piccinini AM, Midwood KS. DAMPening inflammation by modulating TLR signalling. Mediators Inflamm (2010) 2010:1-21. doi:10.1155/2010/672395

136. Suna G, Wojakowski W, Lynch M, Barallobre-Barreiro J, Yin X, Mayr U, et al. Extracellular matrix proteomics reveals interplay of aggrecan and aggrecanases in vascular remodeling of stented coronary arteries. Circulation (2017) 137(2):166-83. doi:10.1161/circulationaha.116.023381

137. Khaleel MS, Dorheim TA, Duryee MJ, Durbin HE Jr, Bussey WD, Garvin RP, et al. High-pressure distention of the saphenous vein during preparation results in increased markers of inflammation: a potential mechanism for graft failure. Ann Thorac Surg (2012) 93(2):552-8. doi:10.1016/j. athoracsur.2011.10.035

138. Karper JC, Ewing MM, de Vries MR, de Jager SC, Peters EA, de Boer HC, et al. TLR accessory molecule RP105 (CD180) is involved in post-interventional vascular remodeling and soluble RP105 modulates neointima formation. PLoS One (2013) 8(7):e67923. doi:10.1371/journal.pone.0067923

139. Bezhaeva T, Wong C, de Vries MR, van der Veer EP, van Alem CMA, Que I, et al. Deficiency of TLR4 homologue RP105 aggravates outward remodeling in a murine model of arteriovenous fistula failure. Sci Rep (2017) 7(1):10269. doi:10.1038/s41598-017-10108-4

140. Karper JC, de Jager SC, Ewing MM, de Vries MR, Bot I, van Santbrink PJ, et al. An unexpected intriguing effect of toll-like receptor regulator RP105 (CD180) on atherosclerosis formation with alterations on B-cell activation. Arterioscler Thromb Vasc Biol (2013) 33(12):2810-7. doi:10.1161/ ATVBAHA.113.301882

141. Wezel A, van der Velden D, Maassen JM, Lagraauw HM, de Vries MR, Karper JC, et al. RP105 deficiency attenuates early atherosclerosis via decreased monocyte influx in a CCR2 dependent manner. Atherosclerosis (2015) 238(1):132-9. doi:10.1016/j.atherosclerosis.2014.11.020

142. Kupreishvili K, Meischl C, Vonk ABA, Stooker W, Eijsman L, Blom AM, et al. Arterial blood pressure induces transient C4b-binding protein in human saphenous vein grafts. Ann Vasc Surg (2017) 41:259-64. doi:10.1016/j. avsg.2016.10.033

143. Smith PK, Shernan SK, Chen JC, Carrier M, Verrier ED, Adams PX, et al. Effects of C5 complement inhibitor pexelizumab on outcome in high-risk coronary artery bypass grafting: combined results from the PRIMO-CABG I and II trials. J Thorac Cardiovasc Surg (2011) 142(1):89-98. doi:10.1016/j. jtcvs.2010.08.035

144. Shi GP, Bot I, Kovanen PT. Mast cells in human and experimental cardiometabolic diseases. Nat Rev Cardiol (2015) 12(11):643-58. doi:10.1038/ nrcardio.2015.117

145. Cross KS, el-Sanadiki MN, Murray JJ, Mikat EM, McCann RL, Hagen PO. Mast cell infiltration: a possible mechanism for vein graft vasospasm. Surgery (1988) 104(2):171-7.

146. Willems S, Vink A, Bot I, Quax PH, de Borst GJ, de Vries JP, et al. Mast cells in human carotid atherosclerotic plaques are associated with intraplaque microvessel density and the occurrence of future cardiovascular events. Eur Heart J (2013) 34(48):3699-706. doi:10.1093/eurheartj/eht186

147. Schober A. Chemokines in vascular dysfunction and remodeling. Arterioscler Thromb Vasc Biol (2008) 28(11):1950-9. doi:10.1161/ATVBAHA.107.161224

148. Cherian SM, Bobryshev YV, Liang H, Inder SJ, Wang AY, Lord RS, et al. Immunohistochemical and ultrastructural evidence that dendritic cells infiltrate stenotic aortocoronary saphenous vein bypass grafts. Cardiovasc Surg (2001) 9(2):194-200. doi:10.1016/S0967-2109(00)00102-2

149. Ozmen J, Bobryshev YV, Lord RS. CD40 co-stimulatory molecule expression by dendritic cells in primary atherosclerotic lesions in carotid arteries and in stenotic saphenous vein coronary artery grafts. Cardiovasc Surg (2001) 9(4):329-33. doi:10.1016/S0967-2109(00)00141-1

150. Andersson J, Libby P, Hansson GK. Adaptive immunity and atherosclerosis. Clin Immunol (2010) 134(1):33-46. doi:10.1016/j.clim.2009.07.002

151. Carpenter JP, Tomaszewski JE. Human saphenous vein allograft bypass grafts: immune response. J Vasc Surg (1998) 27(3):492-9. doi:10.1016/ S0741-5214(98)70323-4

152. Hilker M, Buerke M, Lehr HA, Oelert H, Hake U. Bypass graft disease: analysis of proliferative activity in human aorto-coronary bypass grafts. Heart Surg Forum (2002) 5(Suppl 4):S331-41.

153. Nosalski R, Guzik TJ. Perivascular adipose tissue inflammation in vascular disease. Br J Pharmacol (2017) 174(20):3496-513. doi:10.1111/bph.13705

154. Mauro CR, Ding K, Xue H, Tao M, Longchamp A, Belkin M, et al. Adipose phenotype predicts early human autogenous arteriovenous hemodialysis remodeling. J Vasc Surg (2016) 63(1):171-6.e1. doi:10.1016/j.jvs.2014.06.110

155. Dashwood MR, Dooley A, Shi-Wen X, Abraham DJ, Dreifaldt M, Souza DS. Perivascular fat-derived leptin: a potential role in improved vein graft performance in coronary artery bypass surgery. Interact Cardiovasc Thorac Surg (2011) 12(2):170-3. doi:10.1510/icvts.2010.247874

156. Dashwood MR, Tsui JC. 'No-touch' saphenous vein harvesting improves graft performance in patients undergoing coronary artery bypass surgery: 
a journey from bedside to bench. Vascul Pharmacol (2013) 58(3):240-50. doi:10.1016/j.vph.2012.07.008

157. Ozen G, Topal G, Gomez I, Ghorreshi A, Boukais K, Benyahia C, et al. Control of human vascular tone by prostanoids derived from perivascular adipose tissue. Prostaglandins Other Lipid Mediat (2013) 107:13-7. doi:10.1016/j. prostaglandins.2013.06.002

158. Drosos I, Chalikias G, Pavlaki M, Kareli D, Epitropou G, Bougioukas G, et al. Differences between perivascular adipose tissue surrounding the heart and the internal mammary artery: possible role for the leptin-inflammation-fibrosis-hypoxia axis. Clin Res Cardiol (2016) 105(11):887-900. doi:10.1007/ s00392-016-0996-7

159. Danek BA, Karatasakis A, Alame AJ, Nguyen-Trong PJ, Karacsonyi J, Rangan B, et al. Saphenous vein graft near-infrared spectroscopy imaging insights from the lipid core plaque association with clinical events near-infrared spectroscopy (ORACLE-NIRS) registry. Catheter Cardiovasc Interv (2017) 89(6):E172-80. doi:10.1002/ccd.26696

160. Butany JW, David TE, Ojha M. Histological and morphometric analyses of early and late aortocoronary vein grafts and distal anastomoses. Can J Cardiol (1998) 14(5):671-7.

161. Muto A, Model L, Ziegler K, Eghbalieh SD, Dardik A. Mechanisms of vein graft adaptation to the arterial circulation: insights into the neointimal algorithm and management strategies. Circ J (2010) 74(8):1501-12. doi:10.1253/ circj.CJ-10-0495

162. Sakakura K, Nakano M, Otsuka F, Yahagi K, Kutys R, Ladich E, et al. Comparison of pathology of chronic total occlusion with and without coronary artery bypass graft. Eur Heart J (2014) 35(25):1683-93. doi:10.1093/ eurheartj/eht 422

163. Westerband A, Mills JL, Marek JM, Heimark RL, Hunter GC, Williams SK. Immunocytochemical determination of cell type and proliferation rate in human vein graft stenoses. J Vasc Surg (1997) 25(1):64-73. doi:10.1016/ S0741-5214(97)70322-7

164. Oksuz F, Elcik D, Yarlioglues M, Duran M, Ozturk S, Celik IE, et al. The relationship between lymphocyte-to-monocyte ratio and saphenous vein graft patency in patients with coronary artery bypass graft. Biomark Med (2017) 11:867-76. doi:10.2217/bmm-2017-0079

165. de Vries MR, Quax PH. Plaque angiogenesis and its relation to inflammation and atherosclerotic plaque destabilization. Curr Opin Lipidol (2016) 27(5):499-506. doi:10.1097/mol.0000000000000339

166. Belch JJ, Dormandy J, Biasi GM, Cairols M, Diehm C, Eikelboom B, et al. Results of the randomized, placebo-controlled clopidogrel and acetylsalicylic acid in bypass surgery for peripheral arterial disease (CASPAR) trial. J Vasc Surg (2010) 52(4):825-33. doi:10.1016/j.jvs.2010.04.027

167. Deo SV, Dunlay SM, Shah IK, Altarabsheh SE, Erwin PJ, Boilson BA, et al. Dual anti-platelet therapy after coronary artery bypass grafting: is there any benefit? A systematic review and meta-analysis. J Card Surg (2013) 28(2):109-16. doi:10.1111/jocs.12074

168. Fujita H, Banno H, Yamanouchi D, Kobayashi M, Yamamoto K, Komori K. Pitavastatin inhibits intimal hyperplasia in rabbit vein graft. J Surg Res (2008) 148(2):238-43. doi:10.1016/j.jss.2007.08.017

169. Tang J, Lobatto ME, Hassing L, van der Staay S, van Rijs SM, Calcagno C, et al. Inhibiting macrophage proliferation suppresses atherosclerotic plaque inflammation. Sci Adv (2015) 1(3)1-9. doi:10.1126/sciadv.1400223
170. Winchester DE, Wen X, Xie L, Bavry AA. Evidence of pre-procedural statin therapy a meta-analysis of randomized trials. J Am Coll Cardiol (2010) 56(14):1099-109. doi:10.1016/j.jacc.2010.04.023

171. Margaritis M, Channon KM, Antoniades C. Statins and vein graft failure in coronary bypass surgery. Curr Opin Pharmacol (2012) 12(2):172-80. doi:10.1016/j.coph.2012.01.009

172. Kang S, Liu Y, Liu XB. Effects of aggressive statin therapy on patients with coronary saphenous vein bypass grafts: a systematic review and meta-analysis of randomized, controlled trials. Clin Ther (2013) 35(8):1125-36. doi:10.1016/j. clinthera.2013.06.006

173. Taggart DP, Ben GY, Lees B, Patel N, Webb C, Rehman SM, et al. A randomized trial of external stenting for saphenous vein grafts in coronary artery bypass grafting. Ann Thorac Surg (2015) 99(6):2039-45. doi:10.1016/j. athoracsur.2015.01.060

174. Stooker W, Niessen HW, Baidoshvili A, Wildevuur WR, Van Hinsbergh VW, Fritz J, et al. Perivenous support reduces early changes in human vein grafts: studies in whole blood perfused human vein segments. J Thorac Cardiovasc $\operatorname{Surg}(2001)$ 121(2):290-7. doi:10.1067/mtc.2001.111656

175. Lardenoye JH, de Vries MR, Grimbergen JM, Havekes LM, Knaapen MW, Kockx MM, et al. Inhibition of accelerated atherosclerosis in vein grafts by placement of external stent in apoE $^{\star} 3$-Leiden transgenic mice. Arterioscler Thromb Vasc Biol (2002) 22(9):1433-8. doi:10.1161/01.ATV. $0000030339.79524 .6 \mathrm{E}$

176. Longchamp A, Alonso F, Dubuis C, Allagnat F, Berard X, Meda P, et al. The use of external mesh reinforcement to reduce intimal hyperplasia and preserve the structure of human saphenous veins. Biomaterials (2014) 35(9):2588-99. doi:10.1016/j.biomaterials.2013.12.041

177. Ben-Gal Y, Taggart DP, Williams MR, Orion E, Uretzky G, Shofti R, et al. Expandable external support device to improve saphenous vein graft patency after CABG. J Cardiothorac Surg (2013) 8:122. doi:10.1186/1749-8090-8-122

178. Ferrari E, von SL, Berdajs D. Improving coronary artery bypass graft durability: use of the external saphenous vein graft support. Multimed Man Cardiothorac Surg (2015) 2015:1-7. doi:10.1093/mmcts/mmv005

179. Meirson T, Orion E, Di Mario C, Webb C, Patel N, Channon KM, et al. Flow patterns in externally stented saphenous vein grafts and development of intimal hyperplasia. J Thorac Cardiovasc Surg (2015) 150(4):871-8. doi:10.1016/j.jtcus.2015.04.061

180. Webb CM, Orion E, Taggart DP, Channon KM, Di Mario C. OCT imaging of aorto-coronary vein graft pathology modified by external stenting: 1-year post-surgery. Eur Heart J Cardiovasc Imaging (2016) 17(11):1290-5. doi:10.1093/ehjci/jev310

Conflict of Interest Statement: The authors declare that the research was conducted in the absence of any commercial or financial relationships that could be construed as a potential conflict of interest.

Copyright $\odot 2018$ de Vries and Quax. This is an open-access article distributed under the terms of the Creative Commons Attribution License (CC BY). The use, distribution or reproduction in other forums is permitted, provided the original author $(s)$ or licensor are credited and that the original publication in this journal is cited, in accordance with accepted academic practice. No use, distribution or reproduction is permitted which does not comply with these terms. 